\title{
Feasibility Study of Solar Cooling Thermally Driven System Configurations for an Office Building in Mediterranean Area
}

\author{
Luca Cirillo *, Alessandro Della Corte and Sergio Nardini \\ Seconda Università degli Studi di Napoli, Dipartimento di Ingegneria Industriale e \\ dell'Informazione, Aversa, Caserta, Italy \\ Email: 1cirillo87@gmail.com
}

\begin{abstract}
The high temperature values in the summer time in southern Europe involve a high demand of energy for air conditioning. The advantage of solar cooling is the simultaneity of strong sunlight and cooling requirement. In fact, when the demand of electricity reaches extreme peaks for the excessive use of air conditioners, heat energy from the sun it is available.

In this paper, an analysis with NEGST (New Generation of Solar Thermal System) feasibility study for a solar cooling plant in southern part of Italy (Naples) is carried out. The building is an office of a chemical industry. It is $48 \mathrm{~m}$ long, $23 \mathrm{~m}$ wide and $3.5 \mathrm{~m}$ high, and 200 people work inside. Thermal loads by machines, people, PC etc. were evaluated by means the software Energy Plus. It is considered three different type of collectors (FPC, ETC and PTC) and two different chillers: single effect for collectors FPC and ETC and double effect $\left(\mathrm{H}_{2} \mathrm{O}-\mathrm{BrLi}\right)$ for the collectors PTC.

Results are given in terms of solar fraction and PE-Saving for three different configurations. Then, it calculated the payback time for the best plant configuration.
\end{abstract}

Keywords: Solar heating and cooling, Solar energy, Absorption cooling, Simulation.

\section{INTRODUCTION}

Absorption cooling technology can be used in air conditioning and refrigeration for the residential sector; it is also a more environmentally-friendly option since the system uses thermal energy to produce cold which allows the use of solar thermal energy, waste heat and other sources of low enthalpy heat. Recently a new type of advanced absorption cycles have been developed that are even available commercially in large capacities, including multiple-effect cycles.

Solar energy represents an attractive option to decrease the electricity and fossil fuels consumption as well as the dependency of imported energy [1]. Solar thermal cooling systems are also very attractive when solar thermal energy is used for other needs (DHW and space heating) [2,3].

Numerous studies have been conducted in the field of solar assisted absorption chillers.

Currently, the majority of solar absorption cooling systems use $\mathrm{LiBr}-\mathrm{H}_{2} \mathrm{O}$ as working fluids. Research, involving simulation analysis and experimental research, has been reported [4-10]. Assilzadeh et al. [4] conducted a simulation and optimization of a solar absorption cooling system with evacuated tubes which will be designed for Malaysia and other similar tropical regions. To operate the system continuously and to increase its profitability, the system required a storage tank of $0.8 \mathrm{~m}^{3}$ and $35 \mathrm{~m}^{2}$ of evacuated tube collectors with an inclination of $20^{\circ}$. Florides et al. [11] carried out a simulation for a typical house in Cyprus. They modeled a SACS with weather conditions in Nicosia. The optimum configuration consisted of $15 \mathrm{~m}^{2}$ of parabolic collectors with an inclination of $30^{\circ}$ on the horizontal, a 0.6 $\mathrm{m}^{3}$ hot water storage tank and a $\mathrm{LiBr}-\mathrm{H}_{2} \mathrm{O}$ as working fluid which could cover the load of a typical house throughout the year. Luna [12] worked on simulation of an integrated system that provides heating, cooling and hot water for domestic use from a system activated which a hybrid solar/natural gas power source using a Yazaki $35 \mathrm{~kW}$ absorption cooler for a housing project located in Mexicali, Mexico. It is determined an area of $104 \mathrm{~m}^{2}$, the volume of $6 \mathrm{~m}^{3}$ for the storage tank, and the optimal temperature set point $\left(75^{\circ}\right)$ of the auxiliary heater thermostat. The reduction of emissions to the atmosphere was estimated at $9 \mathrm{tCO}_{2}$ per year with respect to a vapor compression cooling system.

The solar absorption chillers designed in the world are composed with single-effect chillers and low-temperature solar thermal flat plate or evacuated tube collectors (FPC and ETC) $[13,14]$. The handicap of solar single effect chillers is the values chiller's COP, in fact, they require an high collector area to meet the thermal energy demand. Sometimes the available rooftop areas is small, so a large collector area for FPC collectors may be too expensive. Mazloumi et al. [5] designed a plant with a single-effect absorption chiller and with parabolic through collector (PTC) in order to meet the thermal energy demand of an house. Their results shown that the collector mass flow rate allows a good effect on the optimal capacity of the storage tank and a negligible effect on the minimum required collector area. Balghouthi et al. [15] 
developed a feasibility study of a solar cooling system with single effect absorption chillers in the Tunisian weather. They carried out an analysis by varying storage tank capacity, collector area and collector slope, they defined the optimal configuration for reliable operation of the system. Said et al. [16] carried out a mathematical analysis on a solar cooling system with single effect absorption chiller system, testing to increase the global COP of the chiller. In their work it is considered the recovery of waste heat from dephlegmator and using of a refrigerant storage unit. The performance of the solar cooling system was analyzed by means Engineering Equation Solver (EES), besides they carried out an experimental study to verify the plant for two days the accuracy of the mathematical model. The results suggested an improvement in the COP of the chiller by $10 \%$ of the dephlegmator heat recovery and by $8 \%$ of the refrigerant storage unit. Shirazi et al. [17] carried out a systematic parametric study and feasibility assessment of solar-assisted single effect, double effect and triple effect absorption chillers for heating and cooling applications. Their results shown that there is not any advantage by using concentrating collector powered multi effect chillers over solar single effect chillers in climates with low direct normal irradiance level. Parabolic through collectors and solar triple effect chiller are used in climates with direct normal irradiance fractions above $60 \%$ because it is necessary that the solar field is small. Reda et al. [18] focused on energy assessment of solar cooling thermally driven system configurations for an office building in a Nordic country. They analyzed two cases, they differs for the hot storage tank connection. In the first configuration only the tank can supply the chiller (Case 1), while in the second, the chiller can be supplied either by the tank or the solar collectors directly (Case 2). Their results show that Case 2 has better performance than Case 1 , because of the versatility shown in summer. Mammoli et al. [19], studied the performance of a solar single effect absorption chiller under different control strategies for summer daytime, summer nighttime, winter daytime and winter nighttime operations. The plant is located at University of New Mexico. Their results showed that the plant solar fraction can be boosted by $60 \%$ if the hot water storage tank is well insulated. Besides, the authors suggested a set of design recommendations for the solar collector array, hot water storage, cold water storage, and air handling units. Several economic studies carried out by many authors. Al-Alili et al. [20] carried out a global analysis of solar cooling system with single effect absorption chiller in order to evaluate their performance under an hot climate present in Abu Dhabi. Their results shown that the proposed system consumed $47 \%$ less electrical energy than the conventional vapor compression cycles, besides they noted that the collector area have a predominant impact on the payback time in terms of economic performance. Eicker et al. [21-23] carried out an energetic and economic performance of a solar cooling system for office buildings under different climates worlwide. Their results showed that it is possible to reduce the primary energy of $40-70 \%$ and the system design and energetic load have important roles in the performance of the system. Regue et al. [24], in their study have tried to minimize losses in order to increase the performance of a solar thermal concentrator. They have carried out an experimental analysis, which consists of converting solar radiation into thermal energy using a cylindrical parabolic solar concentrator. The developed theoretical model involves a number of parameters such as the average monthly solar radiation that allows us to estimate the direct radiation at the reflector, the geometrical concentration and exchange of heat between the opening of the collector and the the receiver, allows the evaluation of the temperature at the latter. This model of concentration leads to levels of temperatures between $70 \mathrm{C}^{\circ}$ to $200 \mathrm{C}^{\circ}$.

Cucumo et al. [25] have carried out a thermodynamic analysis and evaluation of the performance of solar plants with parabolic through collectors cooled by atmospheric air. The plants were studied in two operating modes: at variable flow rate and constant temperature at the outlet collectors, and at constant flow rate and variable outlet temperature. The results obtained demonstrate a very good performance by this type of plant, which utilizes the ambient air in place of the expensive and more problematic fluids such as synthetic oils and molten salts used in already constructed plants; it is very simple from the constructional point of view and does not need any water because the working fluid in the engine is the air and the intercooling of the compressor can also be done by atmospheric air.

This paper reports the results of simulation of energy supply in an office of a chemical industry via solar coolingheating system. It is studied the planning of meeting the energy needs of the office with an optimum level of solar energy. Besides, technical and economic feasibility study of applying an integrated system considering Italian prices of electricity and natural gas by using software.

\section{SYSTEM DESCRIPTION AND INPUT DATA}

The solar cooling absorption systems investigated in this work are based first of all on low temperature solar thermal collectors with single effect absorption chiller; subsequently it is investigated a solar cooling system with high temperature solar thermal collectors coupled with multi-effect $\mathrm{LiBr}-\mathrm{H}_{2} \mathrm{O}$ absorption chillers.

The systems are designed to meet both space heating and cooling demand of a building, besides the plant is designed to work all the year. In addition, the system also meets the needs of hot water for a laundry and for bathrooms in the building object of study.

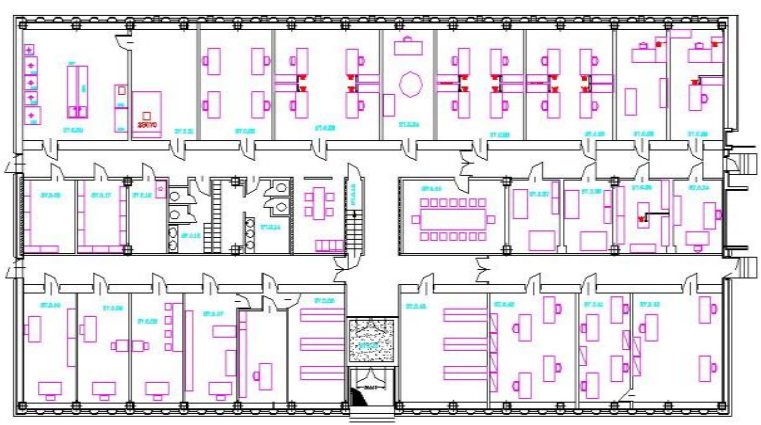

Figure 1. Map of office building

The study focused on different types of commercially available collectors and absorption chillers, three different configurations are presented in this work:

- $\quad \mathrm{SHC1}$

In the SHC1 configuration, flat plate collectors (FPC) and single effect absorption chiller are used.

$\mathrm{SHC} 2$

In the SHC2 configuration, evacuated tubular collectors (ETC) and a single-effect absorption chiller are used.

- $\quad \mathrm{SHC} 3$ 
In the SHC3 configuration, parabolic trough collectors (PTC) are located for the solar field and a double-effect absorption chiller is used.

Figure 1 shows the map of office analyzed. There are 24 PC workstations, 2 bathrooms and 1 laundry room.

Thermal loads by machines, people, PC etc. were evaluated by means the software Energy Plus [24]. Fig. 2 shows the maximum value of the summer load is in August, as it is in this month that it has greater need for cooling; the maximum value of the winter thermal load is obtained in January. It is considered both the solar radiation on tilted surface that the solar radiation normal surface, as it is a comparison was made between three different technologies, two of which with solar field tilted $40^{\circ}$ and oriented to the South, a rather PTC collectors with Est-West orientation. The values of the solar radiation are shown in fig. 3 and 4 . The calculation of the solar radiation on normal surface only concerns the PTC collectors; the calculation refers to an absorbing surface that rotates continuously in order to remain always perpendicular to the sun's rays (normal surface).

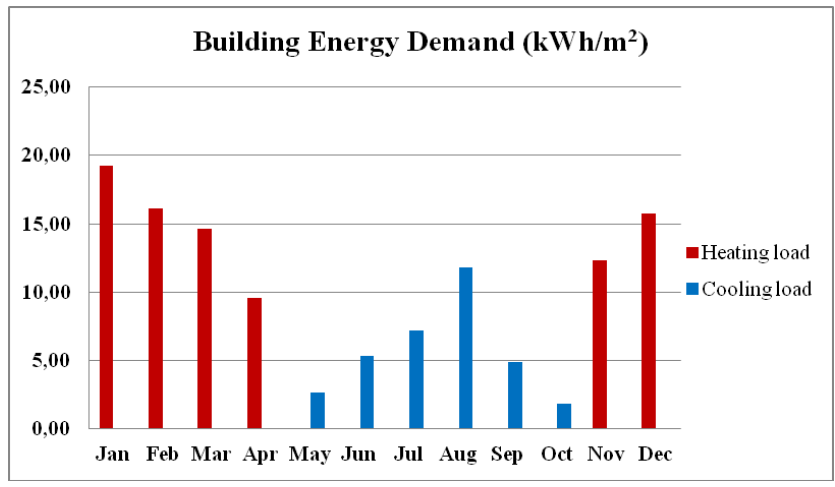

Figure 2. Annual cooling and heating load demand

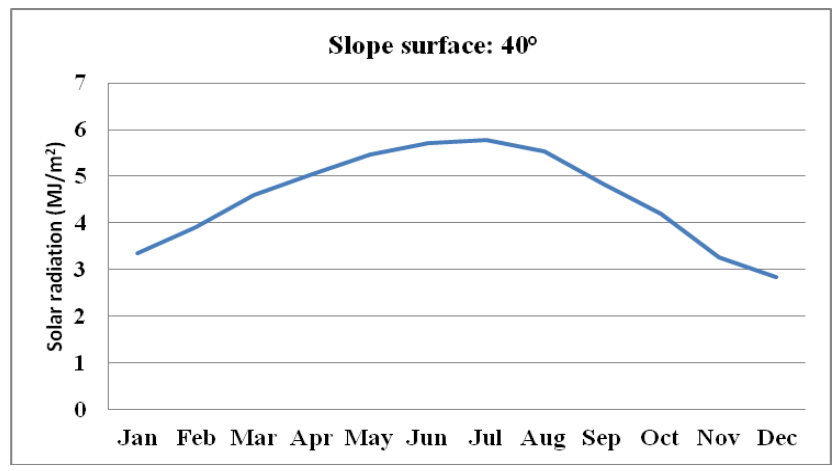

Figure 3. Solar radiation on tilted surface

When the dish is aimed toward the sun, the sun's rays, entering into the opening of the reflector, are reflected from the receiver to the absorber, which converts the energy into heat and transfers it to the heat transfer fluid flowing inside. The absorber of the collector PTC (Parabolic through Collector) has a diameter that depends on the size of the image of the reflected sun and from the production tolerance of the reflecting surface. Usually it is coated with a selective coating that allows a high absorbance for the solar radiation and a low emittance to reduce losses by radiation. The absorber is usually covered by a glass tube in order to reduce convective losses.

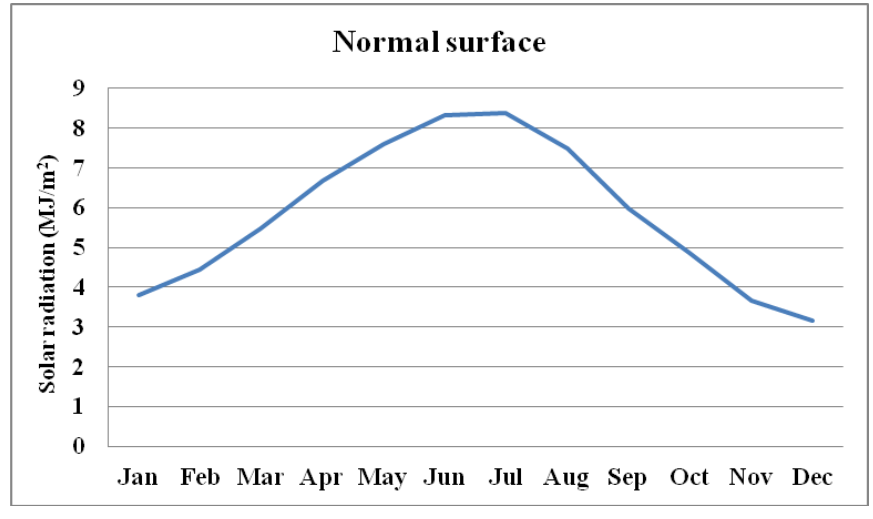

Figure 4. Solar radiation on normal surface

The choice of a technology of a SHC can be activated by different requirements: the coverage of a percentage of thermal loads; the area available for the installation of a solar field (for example, the roof of an industrial plant); the maximum budget available; even more simply, the maximum size that allows access to one of the incentive mechanisms analyzed previously. In this work, it was considered appropriate to dimension a SHC that covers at least more than half of the annual energy requirements through the sun.

The system is designed in accordance with the "cover policy"; then, at least $60 \%$ of the annual demand for energy must be met by the solar heating and cooling system. To this percentage will correspond to a quantity of primary energy saved, evaluated later.

It must be considered that the solar fraction increases with increasing of the total area of the collectors, tending to the unit value: the solar source, in this case, would be able to fully meet the energy requirements of the building. Increasing the area, therefore, reduces the contribution of the energy source, but it increases the cost of the plant.

Figure 5 shows the scheme of the SHC system. The more important components of the plant are solar thermal collectors, three storage tanks, a supplementary boiler, a chiller (the wet cooling tower is incorporated), fan coils for heating and cooling, valves, pumps and control system. The system is designed to allow both space heating and cooling required by the building, besides it is necessary that the solar field work during the whole year. It improves the efficiency and economics of the plant as compared to those producing either chilled or hot water alone.

The energetic performance of the proposed SHC system can be evaluated taking into account two factors: solar fraction (f) and primary energy consumption (PE-Consumed).

Solar fraction is defined as the ratio between energy supplied by solar resources and the total energy demand required by the building. The SHC systems investigated in this work use more than one type of energy carrier (electricity and methane), the primary energy consumption corresponding to each configuration is calculated to provide a common expression of all energy carriers.

The plant in question is a closed cycle system (closed because the heat transfer fluid evolves in a closed cycle).

The energy from the sun is "captured" by the solar collectors, which transform the heat using the heated water (and suitably mixed to a solution) as the operating fluid (water) within a refrigeration cycle. The cold fluid will then be used for the conditioning of environments. In a country like Italy, characterized by very hot summers, solar cooling could well express all its potential. 
The hot storage tank stores heat produced by the solar collectors and then provide it, when necessary, to the refrigerating machine generator. Inside the hot storage tank there is a heat exchanger for the heat exchange between the incoming flow from the solar field and the water present in the accumulation. The fluid leaving the exchanger back into the manifolds to be heated. The water is pressurized ( 4 bars) and maintained in this storage tank at a temperature of $180 / 200^{\circ} \mathrm{C}$. The cold storage tank has the purpose of introducing a gap, in terms of time, between the production of cold by the absorption chiller and its use for air conditioning. This time difference can be several hours, but can also be of some weeks or even months depending on the case that this is a daily or seasonal storage.

So has the role of a real thermal flywheel, and may be essential even in periods in which the absorption machine is in maintenance, ensuring a cold reserve for many hours.

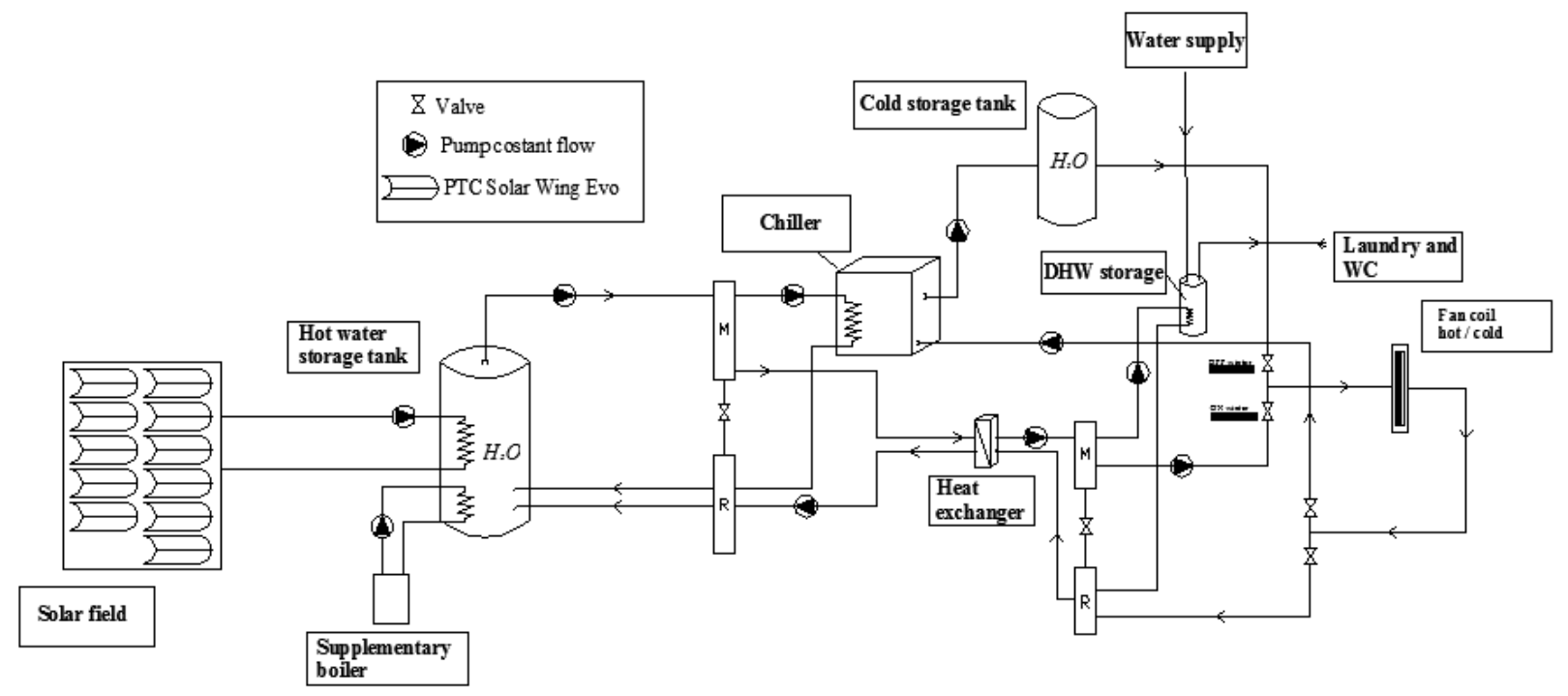

Figure 5. Solar system diagram

Table 1. Components of SHC system

\begin{tabular}{ll}
\hline Component & Size \\
\hline Solar Thermal Collectors (PTC) & $90 \mathrm{~m}^{2}$ \\
Hot storage tank & $5 \mathrm{~m}^{3}$ \\
Cold storage tank & $1 \mathrm{~m}^{3}$ \\
DHW tank & $0.5 \mathrm{~m}^{3}$ \\
Chiller & $70 \mathrm{~kW}$ \\
Pumps, valves and control system & - \\
Heat exchanger & - \\
\hline
\end{tabular}

In the case under review, it is the accumulation of daily type. While the cold accumulations are used only in the summer, or when there is demand for cooling, the hot storage tank side are used both in the summer months than in the winter. In the case in which the accumulation of thermal energy, and therefore the solar field, is not sufficient to meet demand during critical periods, it is necessary that alert at the auxiliary gas burner. This auxiliary gas burner serves to heat the hot water in the accumulation downstream of the solar field up to the temperature required for the proper power of the absorption $\left(140 / 150^{\circ} \mathrm{C}\right)$.

\section{NEW GENERATION OF SOLAR THERMAL SYSTEM (NEGST)}

NEGST [26] was born by European project. The overall objective of this project is to introduce more cost-effective solar thermal systems, particularly for domestic hot water preparation and / or space heating, to the market in order to contribute to the European Union's Action Plans with regard to the reduction of $\mathrm{CO}_{2}-$ Emissions and the cost effective supply of renewable energies. In order to achieve this goal the project provides a framework for the development of the next generation of solar thermal systems and their introduction to the market.

\section{ANALYSIS}

The methodology implemented to perform the thermal analysis of the different solar cooling systems can be summarized in the following main steps:

- Calculation of both cooling and heating loads on monthly basis for the building located in the selected site;

Calculation of the related primary energy consumption of the conventional cooling and heating system to be replaced by solar energy. An electrically driven vapour compression chiller, operating as a heat pump during the winter season, is assumed as the default reference system;

- Calculation of the thermal energy required by the solar system;

- Assumption of a reasonable fraction of the primary energy consumption to be replaced by the solar energy;

- Evaluation of the requested collectors area to obtain the desired primary energy saving.

After the insertion of all the parameters needed for the thermal performance analysis, it is possible to start the calculation. 
Table 2. Collector parameters

\begin{tabular}{lllll}
\hline Parameter & Unit & FPC & ETC & PTC \\
\hline Area & $\mathrm{m}^{2}$ & 2.20 & 3.31 & 8.25 \\
Collector azimuth & $\circ$ & 0 & 0 & 0 \\
Collector orientation & - & South & South & E-W \\
Concentration ratio & - & - & - & 60 \\
Collector slope & & $\circ$ & 40 & \multicolumn{2}{c}{40} & - \\
$\eta_{0}$ & - & 0.78 & 0.72 & 0.72 \\
$\mathrm{c}_{1}$ & $\mathrm{~W} / \mathrm{m}^{2} \mathrm{~K}$ & 3.88 & 1 & 0.60 \\
$\mathrm{c}_{2}$ & $\mathrm{~W} / \mathrm{m}^{2} \mathrm{~K}^{2}$ & 0.011 & 0.005 & 0 \\
\hline
\end{tabular}

\begin{tabular}{|c|c|c|c|c|}
\hline \multicolumn{5}{|c|}{ Heating Load $\mathrm{kWh} / \mathrm{m}^{\mathrm{z}} \mid$ Cooling Laad $\mathrm{kWh} / \mathrm{m}^{\mathrm{z}}$} \\
\hline \multirow{5}{*}{$\begin{array}{l}\text { Conditioned } \\
\text { floor area }\end{array}$} & \multirow{5}{*}{$\mathrm{m}^{2}$} & January & 19.24 & 0.00 \\
\hline & & February & 16.16 & 0.00 \\
\hline & & March & 14.61 & 0.00 \\
\hline & & April & 9.55 & 0.00 \\
\hline & & May & 0.00 & 2.66 \\
\hline \multirow[b]{2}{*}{ Reference CHP: } & & June & 0.00 & 5.36 \\
\hline & & July & 0.00 & 7.20 \\
\hline \multirow[b]{2}{*}{ Heating COP 3.00} & & August & 0.00 & 11.85 \\
\hline & & September & 0.00 & 4.90 \\
\hline \multirow{3}{*}{ Cooling COP 2.50} & & October & 0.00 & 1.85 \\
\hline & & November & 12.32 & 0.00 \\
\hline & & December & 15.75 & 0.00 \\
\hline
\end{tabular}

Figure 6. Input data of NEGST

The result is two plots: a curve reporting the variation of the primary energy saved with respect to the reference conventional system, as a function of the collector area and a chart showing the heating and cooling loads on a monthly basis as well as the solar fraction and solar radiation.

Solar system parameters considered in the case study are shown in table 2 .

In "Reference CHP" of Figure 6 the values of the heat pump coefficient of performance in compression, assumed as the reference heating system (Heating COP), and when it functions as the cooling machine (Cooling COP) are inserted.

The heating and cooling COP of a reference heating/cooling system have to be provided (the default values correspond to the average heating and cooling COP of an electrically driven vapour compression heat pump). This issue allows to evaluate the corresponding primary energy consumed by the heating and cooling machine assumed as the reference system.

The solar field surface adopted in NEGST was always equal to $90 \mathrm{~m}^{2}$ for all the considered technologies; so, doing to remain fixed this value, it is calculated the value of the corresponding solar fraction, which results to be acceptable in the case in which greater than $60 \%$, as determined according to the "criterion of the cover". To have a capacity of actual daily accumulation of six hours, guaranteeing a percentage greater than $60 \%$, it takes at least fifty liters of water per square meter of solar panel field; therefore, the heat accumulation should contain about $5 \mathrm{~m}^{3}$ of water. The accumulation of DHW has been dimensioned considering the demand for water for toilet to use offices and the liters required for the washing of each washing machine present in the laundry. To obtain a correct proportion between the solar field and the amount of accumulated water in the tanks, to 90 $\mathrm{m}^{2}$ of solar field arising from the analysis for the operation of the chiller, are added other $5 \mathrm{~m}^{2}$

About the configuration 1 (SHC1) and the configuration 2 (SHC2), there is the presence of a single-effect absorption chiller, whose operating cycle is shown in figure 7. The choice of this type of machine is strongly dictated by the solar field, because the temperature reached by the evacuated tube collectors is greater than that attainable from the flate plate collectors, but still falling within the range $70-100^{\circ} \mathrm{C}$, values compatible with those suitable for a correct operation of a chiller single effect. About the configuration 3 (SHC3), a chiller double effect lithium bromide - water $(70 \mathrm{~kW})$ is compatible with the PTC collectors. This because the typical double effect machines require heat transfer fluids at high inlet temperatures (around $140-180^{\circ} \mathrm{C}$ ), and the parabolic collectors (PTC) can easily reach these temperatures. In the following paragraph, a comparison was made between the three different solar field of technologies to be able to choose one, and carry out on a second time design considerations to achieve economic and financial analysis.

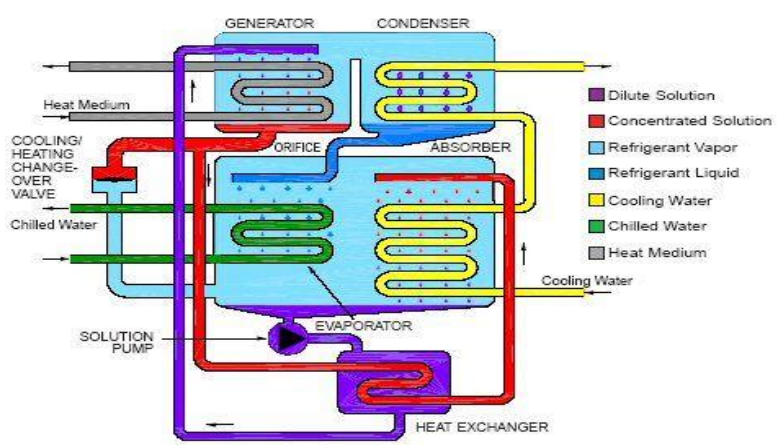

Figure 7. Single effect absorption cycle (cooling)

Table 3. Results of SHC3 system

\begin{tabular}{llllll}
\hline Month & $\begin{array}{l}\mathrm{S}_{\mathrm{rt}} \\
(k W h)\end{array}$ & $\begin{array}{l}\mathrm{H}_{\mathrm{L}} \\
(k W h)\end{array}$ & $\begin{array}{l}\mathrm{C}_{\mathrm{L}} \\
(k W h)\end{array}$ & $\begin{array}{l}\mathrm{Th}_{\mathrm{S}} \\
(k W h)\end{array}$ & $\mathrm{f}-$ \\
\hline January & 26396.86 & 19240 & 0 & 19240 & 0.39 \\
Febraury & 18028.59 & 16160 & 0 & 16160 & 0.42 \\
March & 16340.63 & 14610 & 0 & 14610 & 0.57 \\
April & 14543.77 & 9550 & 0 & 9550 & 0.91 \\
May & 17534.78 & 0 & 2660 & 2418.18 & 1 \\
June & 19333.23 & 0 & 5360 & 4872.73 & 1 \\
July & 20476.69 & 0 & 7200 & 6545.45 & 1 \\
August & 18481.72 & 0 & 11850 & 107772.7 & 1 \\
September & 15646.87 & 0 & 4900 & 4454.55 & 1 \\
October & 18892.09 & 0 & 1850 & 1681.82 & 1 \\
November & 20180.56 & 12320 & 0 & 12320 & 0.5 \\
December & 21870.45 & 15750 & 0 & 15750 & 0.36 \\
\hline
\end{tabular}

\section{RESULTS AND DISCUSSION}

\subsection{System performance}

For each type of solar field adopted, it is made an annual analysis is in terms of primary energy, and the results are shown in Table 4.

Table 4. Annual analysis

\begin{tabular}{ccccc}
\hline & $\begin{array}{c}\text { PE-CHP } \\
{[\mathrm{kWh}]}\end{array}$ & $\begin{array}{c}\text { PE-consumed } \\
{[\mathrm{kWh}]}\end{array}$ & $\begin{array}{c}\text { PE-saving } \\
{[\%]}\end{array}$ & $\begin{array}{c}\mathrm{f} \\
{[-]}\end{array}$ \\
\hline FPC & 106845.00 & 90031.64 & $16 \%$ & 0.40 \\
ETC & 106845.00 & 44517.64 & $58 \%$ & 0.71 \\
PTC & 106845.00 & 49442.70 & $54 \%$ & 0.62 \\
\hline
\end{tabular}


"PE-CHP" are the primary energy consumptions of the reference system, "PE-Consumed" is the consumed primary energy of the back-up unit. The weighted average of the monthly solar fractions results in the annual solar fraction, "f". This table comes from a comparison of the yearly solar fraction that is obtained from the configurations of systems SHC1, SHC2, SHC3. In fact, the next three histograms show the evolution of the annual solar fraction each month.

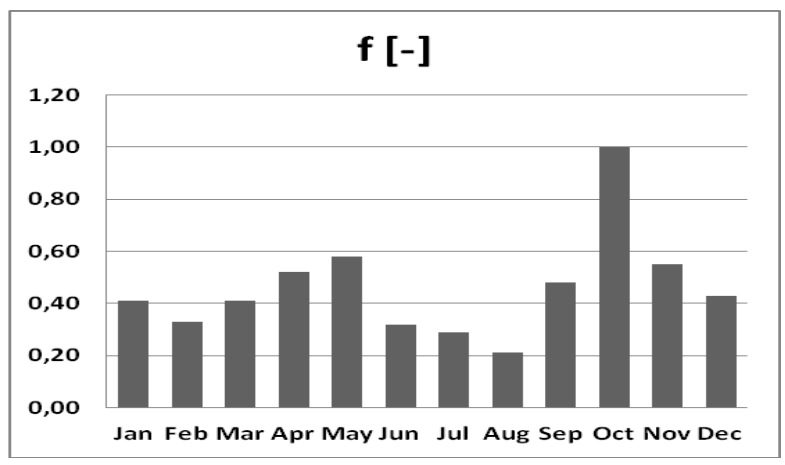

Figure 8. Solar fraction for system SHC1

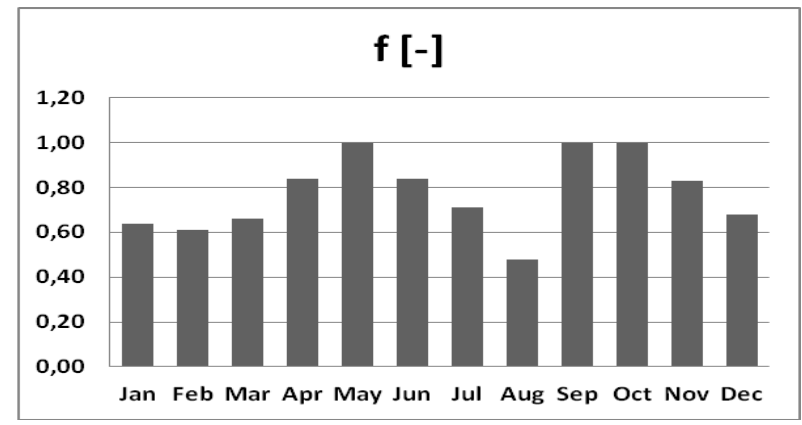

Figure 9. Solar fraction for system SHC2

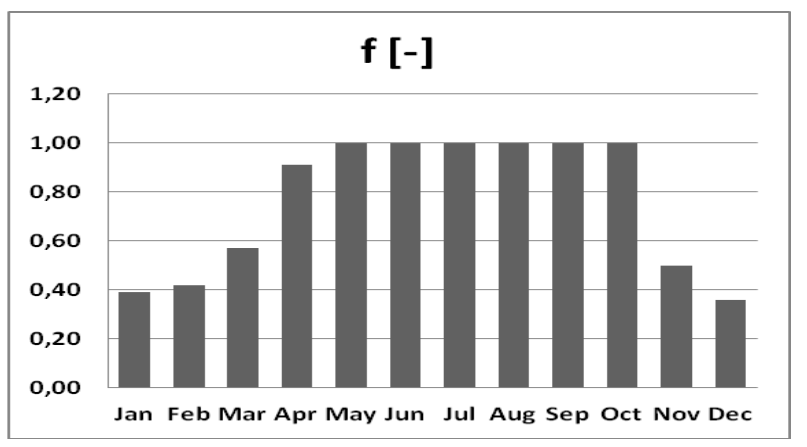

Figure 10. Solar fraction for system SHC3

The graphs show that the annual yield of a plant with evacuated tubular collectors (ETC) is much better than the one where a solar field with flat plate collectors (FPC) is planned; just think of the annual solar fraction calculated with NEGST tool. The main motivation of this result lies in the fact that the evacuated tube collectors $\left(90 \mathrm{~m}^{2}\right.$ fixed as the surface of the solar field value), have a better seasonal efficiency, for the substantial cancellation of thermal losses by convection and conduction related to the presence of a ' vacuum sealing gap. For this particular system (SHC2), it evaluated the influence of the inclination of the solar field on the annual solar fraction (fig. 9); the optimum inclination respect to the horizontal plane is about $40^{\circ}$, as shown in Figure 11.
While achieving an annual value of 0.71 solar fraction, in the summer the ETC technology has a relatively low value of $f$, especially in the months of July and August (respectively 0.71 and 0.48 ); the FPC collectors technology has a low annual efficiency, as with $90 \mathrm{~m}^{2}$ of solar field can annually reach a solar fraction of $40 \%$ (fig. 8): this means that the remaining energy needed by the building must be drawn from supplementary units. But SHC3 deserves a very important consideration: while for the ETC technology the boiler should work even in the summer months to integrate the absorption machine, the PTC technology supplementary boiler can even be switched off throughout the period from May in October, the months when there is a unitary solar fraction $(f=1)$.

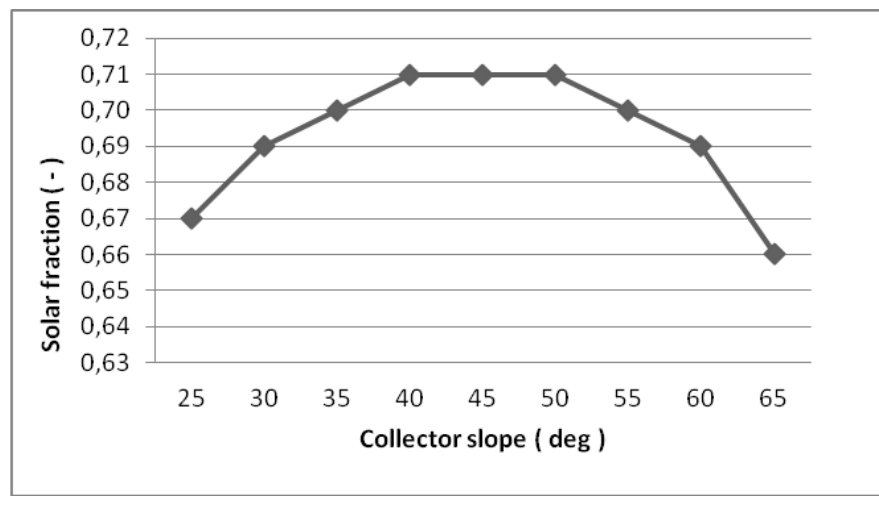

Figure 11. Solar fraction at different collector slope

So, there is a very significant saving electricity for the air conditioning in summer. And in this lies the greatest strength of the parabolic trough collectors; in fact, they could offer their best just when the radiation is greater, that is, during the summer. Solar fraction equal to 0.62 (fig. 10), as happens in the present case (SHC3), involves $54 \%$ of primary energy saved, compared to the conventional system which consists of a heat pump to electrically powered compression, active both in winter and summer. The optimal solar field is shown in table 5 .

Table 5. Optimal solar field

\begin{tabular}{cccc}
\hline Solar field & $\begin{array}{c}\text { PE-CHP } \\
{[\mathrm{kWh}]}\end{array}$ & $\begin{array}{c}\text { PE-saving } \\
{[\mathrm{kWh}]}\end{array}$ & $\begin{array}{c}\text { PE-saving } \\
{[\%]}\end{array}$ \\
\hline 70 & 106845 & 44874.90 & 42 \\
80 & 106845 & 51285.60 & 48 \\
90 & 106845 & 57696.30 & 54 \\
100 & 106845 & 61970.10 & 58 \\
\hline
\end{tabular}

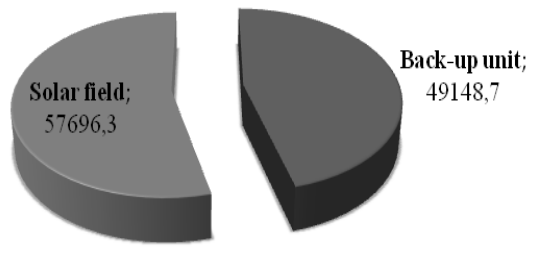

Figure 12. Primary energy savings 


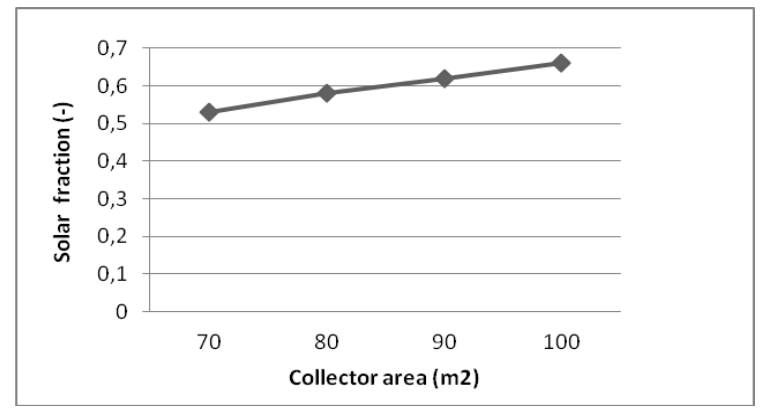

Figure 13. Solar fraction at different collector's surface

Figure 12 shows the energy required by back-up unit (supplementary boiler) and the energy solar developed by solar system. It has been observed if the collector area increases the solar fraction increase (Fig. 13)

\subsection{Financial analysis}

In order to evaluate the economic feasibility of the solar heating and cooling plant, an economic analysis is carried out on the SHC3 configuration taking into account both capital and operating costs of the system. The relevant part of the cost of the SHC absorption systems is the solar field and absorption chiller ( $38000 €$ and $25000 €$ respectively), other components have marginal effects. Investment analysis is carried out by analyzing the cash flows; in addition to cash flows that are produced by the new investment, it is also considered the time factor, in the economic - financial sense.

In total, the plant has an initial cost of $98.000 €$, which coincides with the initial investment; to assess the economic feasibility of the plant, it should be made an estimate of the annual cost savings, cash flows accumulated, the payback time. The following table shows some financial data, including the annual savings in euro, achieved thanks to the construction of the plant; Furthermore, it is essential to consider the annual maintenance and electricity consumption related to the electric pumps, the chiller and control devices. Therefore, this consumption represent an expense that must be addressed in any case every year, but that does not involve serious cash outflow.

Table 6. Economic parameters

\begin{tabular}{lcc}
\hline Investment & 98000.00 & $€$ \\
Incentive & 76500.00 & $€$ \\
Energy cost before SHC & 17095.20 & $€ /$ year \\
Energy cost after SHC & 1691.20 & $€ /$ year \\
Hi (Methane) & 9.94 & $\mathrm{kWh} / \mathrm{Nm}^{3}$ \\
Fuel price & 0.34 & $€ / \mathrm{m}^{3}$ \\
Annual money savings & 15404.00 & $€ /$ year \\
Annual maintenance & 2600.00 & $€ /$ year \\
Fuel inflation rate & 3.50 & $\%$ \\
Interest rate & 5.00 & $\%$ \\
General inflation rate & 3.00 & $\%$ \\
\hline
\end{tabular}

Legislatively in Italy, there are incentives for the production of energy from renewable sources. The duration of the incentive in years is function of the type of intervention; in the present case, the duration is five years. The consumptions are all related to the natural gas that powers the supplementary unit (gas boiler). The annual savings in euro has been assessed as the difference between the cost of primary energy before implantation and after implantation: this value of $15404 €$ is the cost savings achieved at the end of the first year of investment, then, considering the fuel inflation rate, it is estimated the actual cost savings, year by year.

Table 7. Parameters related economic financial analysis

\begin{tabular}{lcc}
\hline NPV (Net Present Value) & $€ 279.805,40$ & $€ 375.689,09$ \\
IRR (Internal Rate return) & $25,9 \%$ & $26,1 \%$ \\
PBT (Pay Back Time) & 3,4 & 3,4 \\
\hline
\end{tabular}

The payback period was calculated as the ratio between the initial investment and the cash flows; clearly, the lower the value of the payback, the lower the investment risk since it would require less time to recover the money invested. NPV and IRR are calculated: NPV represents the profit generated by the investment, expressed in money; IRR is the return offered by the project, calculated on the initial outlay on the basis of cash flows in future periods.

The values reported in Table 7 are referred to an analysis conducted to twenty and twenty-five years. Figure 14 shows the payback period is 3.4 years and the NPV increases linearly with the years.

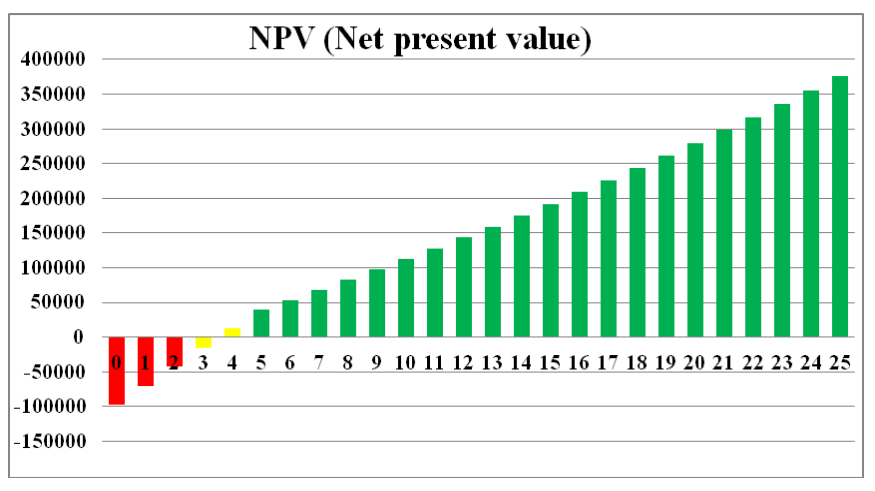

Figure 14. NPV estimated to twenty-five years

\section{CONCLUSIONS}

This study focused on the feasibility of a solar heating and cooling system. The solar field occupies an area of $95 \mathrm{~m}^{2}$ and different storage tanks are present: $0.500 \mathrm{~m}^{3}$ for DHW, 5.00 $\mathrm{m}^{3}$ for the hot water and $2.00 \mathrm{~m}^{3}$ for cold water. A supplementary conventional boiler of $35 \mathrm{~kW}$ is also present. The terminal part of the system is constituted by fan coils, which cools in summer and warm in winter, using a simple and reliable technology based right on the water as the heat transfer fluid.

Main conclusions of this work are:

- In the summer analysis, the PTC collectors are more efficient than ETC and FPC collectors because the supplementary boiler doesn't work in the summer months allowing a minimal consumption of electricity for air conditioning.

- In the winter analysis the ETC collectors are more efficient than ETC and FPC (PE-saving equal to 58\%) because the solar fraction are higher for the winter months.

In the Mediterranean Area the energy required is overall for air conditioning in the summer months, so, the optimal configuration is SHC3. 


\section{REFERENCES}

[1] A. Perdichizzi, A. Birigozzi, G. Franchini and S. Ravelli, "Peak shaving strategy through a solar combined cooling and power system in remote hot climate areas," Appl. Energy, vol. 143, pp. 154-63, 2015. DOI: $10.1016 /$ j.apenergy.2015.01.030.

[2] Solar cooling position paper, Task 38 solar airconditioning and refrigeration. <http://www.ieashc.org/data/sites/1/publications/IEA-SHC-SolarCooling-Position-Paper.pdf $>$

[3] State of the art for solar thermal or PV cooling and refrigeration. Task 53 new generation solar cooling and heating systems (PV or solar thermally driven systems). $<\mathrm{http}: / /$ task53.ieashc.org/data/sites/1/publications/SHC-2014-MugnierSolar-Cooling.pdf>

[4] F. Assilzadeh, S. A. Kalogirou, Y. Ali and K. Sopian, "Simulation and optimization of a $\mathrm{LiBr}$ solar absorption cooling system with evacuated tube collectors," Renew. Energy, vol. 45, 2008, pp. 114359. DOI: $10.1016 /$ j.renene.2004.09.017.

[5] M. Mazloumi, M. Naghashzadegan and K. Javaherdeh, "Simulation of a solar lithium bromide water absorption cooling system with parabolic through collector," Energy Conv. and Manage., vol. 49, 2008, pp. 2820-32. DOI: 10.1016/j.enconman.2008.03.014.

[6] J. P. Praene, O. Marc, F. Lucas and F. Miranville, "Simulation and experimental investigation of solar absorption cooling system in Reunion Island," Appl. Energy, vol. 88, 2011, pp. 831-39. DOI: 10.1016/j.apenergy.2010.09.016.

[7] K. F. Fong, C. K. Lee and T. T. Chow, "Comparative study of solar cooling system with building-integrated solar collectors for use in sub-tropical regions like Hong Kong,” Appl. Energy, vol. 90, pp. 189-95, 2012. DOI: $10.1016 / \mathrm{j}$.apenergy.2011.06.013.

[8] N. Molero-Villar, J. M. Cejudo-Lopez, F. DominguezMu-noz and A. Carillo-Andres, "A comparison of solar absorption system configurations," Sol. Energy, vol. 86. 2012, pp. 242-52. DOI 10.1016/j.solener.2011.09.027.

[9] E. J. Sarabia Escriva, E. V. Lamas Sivila and V. M. Soto Frances, "Air conditioning production by a single effect absorption cooling machine directly coupled to a solar collector field. Application to Spanish climates," Sol. Energy, vol. 85, 2011, pp. 2108-21. DOI: 10.1016/j.solener.2011.05.019.

[10] X. G. Casals, "Solar absorption cooling in Spain: perspectives and outcomes from the simulation of recent installations," Renew. Energy, vol. 31, pp. 1371-89, 2006. DOI: 10.1016/j.renene.2005.07.002.

[11] G. A. Florides, S. A. Kalogirou, S. A. Tassou and L. C. Wrobel, "Modelling and simulation of an absorption solar cooling system for Cyprus," Sol. Energy, vol. 72, no. 1, pp. 43-51, 2002. DOI: 10.1016/S0038-092X(01)00081-0.

[12] A. Luna, Diseno y evaluacion de vivienda energeticamente sustentable (Doctoral thesis), Universidad Autonoma de Baja California, Mexicali, Mexico, 2008.

[13] F. Calise, A. Palombo and L. Vanoli, "Design and dynamic simulation of a novel polygeneration system fed by vegetable oil and by solar energy," Energy Convers. and Manage., vol. 60, 2012, pp. 204-13. DOI: $10.1016 /$ j.enconman.2012.02.014.
[14] M. J. Tienerney, “Options for solar-assisted refrigeration-through collectors and double-effect chillers," Renew. Energy, vol. 32, 2007, pp. 183-99. DOI: $10.1016 /$ j.renene.2006.01.018.

[15] M. Balghouthi, M. H. Chahbani and A. Guizani, "Feasibility of solar absorption air conditioning in Tunisia," Build Environ., vol. 43, pp. 1459-70, 2008. DOI: 10.1016/j.buildenv.2007.08.003.

[16] S. A. M. Said, M. A. I El-Shaarawi and M. U. Siddiqui, "Analysis of a solar powered absorption system," Energy Convers and Manage., vol. 97, pp. 243-52, 2015. DOI: $\underline{10.1016 / j . e n c o n m a n .2015 .03 .046 .}$

[17] A. Shirazi, R. A. Taylor, S. D. White and G. L. Morrison, "A systematic parametric study and feasibility assessment of solar-assisted single-effect, double-effect, and triple-effect absorption chillers for heating and cooling applications," Energy Conv. and Manage., vol. 114, pp. 258-77, 2016. DOI: 10.1016/j.enconman.2016.01.070.

[18] F. Reda, M. Viot, K. Sipila and M. Helm, "Energy assessment of solar cooling thermally driven system configurations for an office building in a Nordic country," Appl. Energy, vol. 166, pp. 27-43, 2016. DOI: $10.1016 /$ j.apenergy.2015.12.119.

[19] A. Mammoli, P. Vorobieff, H. Barsun, R. Burnett and D. Fisher, "Energetic, economic and environmental performance of a solar-thermal-assisted HVAC system," Energy Build., vol. 42, 2010, pp. 1524-35 DOI: $10.1016 /$ j.enbuild.2010.03.023.

[20] A. Al-Alili, M. D. Islam, I. Kubo, Y. Hwang and R. Radermacher, "Modeling of a solar powered absorption cycle for Abu Dhabi," Appl. Energy, vol. 93, 212, pp. 160-7. DOI: 10.1016/j.apenergy.2010.11.034.

[21] U. Eicker, A. Colmenar-Santos, L. Teran, M. Cotrado and D. Borge-Diez, "Economic evaluation of solar thermal and photovoltaic cooling system through simulation different climatic conditions: an analysis in three different cities in Europe," Energy Build, vol. 70, pp. 207-23, 2014,. DOI: 10.1016/j.enbuild.2013.11.061.

[22] U. Eicker, D. Pietruschka, M. Haag and A. Schmitt, "Systematic design and analysis of solar thermal cooling systems in different climates," Renew. Energy, vol. 80, pp. 827-36, 2015. DOI: 10.1016/i.renene.2015.02.019.

[23] U. Eicker, D. Pietruschka and M. Haag, A. Schmitt, "Comparison of photovoltaic and solar thermal cooling systems for office buildings in different climates," Sol. Energy, vol. 118, pp. 243-55, 2015. DOI: 10.1016/j.solener.2015.05.018.

[24] M. H. Regue, T. Benchatti, A. Medjelled and A. Benchatti, "Improving the performances of a solar cylindrical parabolic dual reflection Fresnel mirror (Experimental part)," vol. 32, pp. 171-8, 2014.

[25] M. Cucumo, V. Ferraro, D. Kaliakatsos and V. Marinelli, "A calculation model for a thermodynamic analysis of solar plants with parabolic collectors cooled by air envolving in an open Joule-Brayton cycle," International Journal of Heat and Technology, vol. 31, pp. 127-34, 2013. DOI: 10.18280/ijht.310217.

[26] http://www.swt-technologie.de/html/negst.html.

[27] http://apps1.eere.energy.gov/buildings/energyplus/ 
NOMENCLATURE

$\mathrm{c}_{1}$

$\mathrm{c}_{2}$

$\mathrm{C}_{\mathrm{L}}$

ETC

$\mathrm{f}$

FPC

$\mathrm{H}_{\mathrm{L}}$

PE
Collector's coefficient $\left(\mathrm{W} / \mathrm{m}^{2} \mathrm{~K}\right)$

Collector's coefficient $\left(\mathrm{W} / \mathrm{m}^{2} \mathrm{~K}^{2}\right.$ )

Cooling load ( $\mathrm{kW} \mathrm{h}$ )

Evacuated tube collector

Solar fraction

Flat plate collector

Heating load (kWh)

Primary energy $(\mathrm{kW} h)$
Parabolic through collector

Solar heating and cooling system

$\mathrm{S}_{\mathrm{rt}}$

Solar radiation on tilted surface $(\mathrm{kW} \mathrm{h})$

Thermal load required (kW h)

\section{Greek symbols}

$\eta_{0}$

Collector's efficiency 